\title{
Perceptions of Racism in Hurricane Katrina: A Liberation Psychology Analysis
}

\author{
Glenn Adams* \\ University of Kansas and University of Toronto
}

\section{Laurie T. O'Brien}

Tulane University

\section{Jessica C. Nelson \\ University of Kansas}

Poll data showed that African Americans perceived more racism in the response to Hurricane Katrina than did White Americans. In this article, we consider claims about racism in Katrina-related events in light of (a) our program of experimental research on group differences in perception of racism and (b) the meta-theoretical perspective of Liberation Psychology (LP). First, this analysis suggests that White Americans may perceive less racism in the Katrina disaster because they are less likely than African Americans to know about historically documented acts of past racism (e.g., following the Mississippi flood of 1927). Second, group differences may arise because African Americans and White Americans face divergent motivations regarding perception of racism. Whereas African Americans may have motivations to be vigilant for the possibility of racism, White Americans may be motivated to deny racism because it constitutes a threat to social identity and to the legitimacy of the status quo.

Here I go, playing the "race card" again. But I can't see the neglect of tens of thousands of victims of Hurricane Katrina-battered New Orleans, who are still trapped in that cesspool

\footnotetext{
${ }^{*}$ Correspondence concerning this article should be addressed to Glenn Adams, Department of Psychology, University of Kansas, 1415 Jayhawk Boulevard, Lawrence, KS 66045-7556 [e-mail: adamsg@ku.edu].

We thank Hazel Rose Markus and the Culture and Psychology Research group at the University of Kansas for their comments on earlier versions of the chapter.
} 
of toxic industrial waste, heavy metals, and human and animal carcasses that was once the proud Crescent City, through any prism except the racial lens.

_Askia Muhammad (2005), journalist and editor of the Black Journalism Review

A truly deplorable aftermath of Katrina is the far left's attempts to stir up racial divisions and the news media's fanning of those flames... Do tornadoes in Kansas have a "racial dimension," a racial animus? Would the Washington Post ever dream up a headline for that? Apparently, America is so stacked with racism in the air that it's in the gale-force winds.

—Brian Bozell, (2005), president of the politically conservative Media Research Center

One of the most striking phenomena to emerge in the aftermath of Hurricane Katrina has been a stark difference in perceptions of the role that racism has played in the disaster and recovery. For some, it is difficult to see events of Katrina "through any prism except the racial lens" (Muhammed, 2005). For others, claims about racism in the context of Katrina are "deplorable" acts of hatred mongering for political gain (Bozell, 2005). Independent polls suggest that there are cultural differences in these perceptions. Specifically, roughly $60 \%$ of African American respondents, but fewer than $20 \%$ of European American respondents, agreed that the government response to Katrina would have been faster if most victims had been White (Page \& Puente, 2005). Similarly, 71\% of African American respondents, but only $32 \%$ of European American respondents, agreed that events of Katrina showed that racial inequality is still a major problem (Pew Research Center for the People and the Press, 2005).

In this article, we consider claims about racism in Katrina in light of two sources: our program of experimental research on group differences in perception of racism and the meta-theoretical perspective of Liberation Psychology (LP), developed by the late Ignatio Martín-Baró (1994) as a means to apply the methods and insights of social psychology to the cause of social justice. ${ }^{1}$ Space does not permit an extended discussion of the LP perspective. Instead we focus on three central tenets of a LP analysis: adopting the perspective of the oppressed, recovering historical memory, and de-ideologizing everyday experience (Martín-Baró, 1994, p. 30). We consider perceptions of racism in Katrina and discuss implications for policy in light of these ideas.

\footnotetext{
${ }^{1}$ Martín-Baró was a social psychologist, trained at the University of Chicago, who was teaching at Central American University in El Salvador when he was assassinated in late 1989. In addition to his identity as social psychologist, Martín-Baró also had an identity as a Jesuit priest who worked among impoverished people in rural El Salvador. The concept of liberation psychology results from the intersection of these identities: an application of social-psychological methods and insights toward the goal of social justice.
} 


\section{Perceptions of Racism Relevant to Hurricane Katrina}

Before beginning this analysis, it is useful to review claims about racism in Katrina-related events. As suggested by poll data, one set of claims about racism concerns the speed and quality of responses to the disaster. Minister Louis Farrakhan said, "I firmly believe if the people on those rooftops had blond hair and blue eyes and pale skin, something would have been done in a more timely manner" (Reuters, 2005). In contrast, President Bush vehemently denied that the slow response was due to racism, saying on one occasion that "The storm didn't discriminate and neither will the recovery effort. When those Coast Guard choppers ... were pulling people off roofs, they didn't check the color of a person's skin"(Page $\&$ Puente, 2005). Observers also perceived differences in responses to people who helped themselves to supplies in the aftermath of the storm, claiming that authorities treated Black residents as criminals_-applying excessive force, firing warning shots, and subjecting them to degrading treatment (Herbert, 2005) - to a greater extent than they did to White residents. Some have also questioned whether racism played a role in the decision to block passage of primarily Black citizens who attempted to flee New Orleans by foot across a bridge into a predominantly White suburb (Brown, 2005).

Another set of claims about racism concerns media coverage. A famous example cited by Julian Bond, chairman of the National Association for the Advancement of Colored People, concerned the differential representation of acts depicted in similar photographs (Bond, 2005). Specifically, an Associated Press photo showed a Black man wading through chest-deep water with grocery store merchandise and described this action as "looting a grocery store" whereas a similar Agence France-Presse photo of two White people described this action as "finding bread and soda from a local grocery store" (Kinny, 2005; Washington, 2005). Jesse Jackson, members of the Congressional Black Caucus, and other Black leaders have also argued that the media use of the word refugee to refer to Katrina survivors carries a racist connotation of second-class citizenship (Washington, 2005). More generally, poll data indicates that $77 \%$ of Black respondents, but only $37 \%$ of White respondents, were bothered when reports referred to evacuated residents as refugees (Page \& Puente, 2005).

Perceptions of racism were not limited to past events, but also extended to suspicions about racism in future events. Residents of many New Orleans neighborhoods expressed suspicions about racism in plans for rebuilding the city. In particular, they expressed concern that authorities will treat Katrina as a natural demolition force, evict former residents from their devastated homes, and use the opportunity to gentrify the city. Subsequent events indicate that these suspicions were justified (Beaumont, 2005; Davis, 2005; Klein, 2005).

Finally, perceptions of racism were evident in what many would describe as "conspiracy beliefs," including the allegation that levees were deliberately 
breached to save predominantly White parts of the city at the expense of predominantly Black parts of the city (Crowley, 2005). A columnist for the Washington Post said that he was "stunned" by the number of Black New Orleanians who believed the levees were sabotaged. "These are not wild-eyed people. They are reasonable, sober people who really believe that" (Fischer, 2005). As the quote implies, the mainstream response to this suggestion that levees may have been deliberately breached has been to label it "paranoia" (Hicks, 2005).

\section{A LP Analysis of Group Differences in Perception of Racism}

Although beliefs about racism in Katrina-related events are widely distributed across groups, media polls and scientific research show that people identified with historically oppressed groups are more likely than people identified with dominant groups to perceive racism in everyday, North American society (Adams, Tormala, \& O’Brien, 2006; Operario \& Fiske, 2001; Rodin, Price, Bryson, \& Sanchez, 1990). Accounts of these differences in both mainstream media (e.g., Hicks, 2005) and psychological science (e.g., Crocker, Luhtanen, Broadnax, \& Blaine, 1999; Johnson, Simmons, Trawalter, Ferguson, \& Reed, 2003) frequently focus on oppressed group patterns as the anomalous phenomena that require explanation. Implicit in this focus is a construction of mainstream American accounts as a straightforward reflection of the fact that does not require further explanation - an objective standard from which people from oppressed groups deviate by overstating the amount of racism in events.

\section{Adopting the Perspective of the Oppressed}

In contrast, the defining meta-theoretical strategy of a LP analysis is a selfconscious attempt to approach phenomena from the perspective of the oppressed. The point of this strategy is not to sacrifice objectivity for political goals (e.g., solidarity with oppressed masses), but rather the scientific goal of a more "objective" account of events (see Martín-Baró, 1994). A LP analysis promotes a more "accurate" analysis, not by treating the perspective of the oppressed as an objective standard, but rather by providing a mindful corrective to the typically unrecognized, cultural grounding of science in mainstream thought. As the cultural approach to social psychology makes increasingly clear, the common-ground assumptions that inform psychological science do not represent an objective "view from nowhere" (Nagel, 1986); instead, they are grounded in particular constructions of reality that often remain invisible in mainstream accounts of phenomena (Fiske, Kitayama, Markus, \& Nisbett, 1998; Gergen, Gulerce, Lock, \& Misra, 1996). This invisibility promotes a collective form of naïve realism (Ross \& Ward, 1996), even among trained scientists, by which observers of a phenomenon believe themselves to have unmediated access to objective reality and remain unaware of the extent to which 
their experience is necessarily mediated through processes of reality construction (e.g., anchoring and objectification, Moscovici, 1984; mutual constitution, Fiske et al., 1998; and subjective construal; Griffin \& Ross, 1991). Resonating with a cultural approach to social psychology, a LP analysis suggests that one can achieve a more "objective" account of events not by deluding oneself about the possibility of achieving a view from nowhere, but instead by self-conscious cultivation of different perspectives on a phenomenon-especially the typically excluded perspectives of the oppressed and powerless.

\section{Application to Katrina Events}

When media observers and social scientists take oppressed group tendencies to claim racism in Katrina as the anomaly that requires explanation, they reinforce a construction of White American perceptions as an objective standard. Judging responses against this standard, they imply that African American tendencies constitute exaggeration or overstatement of the "true" level of racism. In contrast, a LP analysis stresses that dominant group patterns are not a dispassionate reflection of natural reality, but instead constitute social-psychological phenomena that also require explanation. From this perspective, the tendency for White Americans to perceive less racism in Katrina events is not an "objective" account, but instead may deviate from objectivity by understating the "true" level of racism.

Besides shifting the focus of explanation, another way in which the strategy of adopting the perspective of the oppressed informs perceptions of racism in Katrina concerns definitions of racism and conceptualizations of racial inequality. White Americans tend to view racial inequality as a result of the personal or cultural attributes of African Americans (Kluegel \& Smith, 1986; Kluegel \& Bobo, 1993; Lopez, Gurin, \& Nagda, 1998). To the extent that White Americans are aware that racism contributes to inequality, they tend to see it as a localized problem of biased individuals engaging in intentional acts of differential treatment rather than a systemic phenomenon embedded in cultural and institutionalized practices (Kluegel \& Bobo, 1993). Accordingly, when contemplating whether racism affected Katrina events, White Americans may be likely to consider whether specific individuals intentionally acted with the explicit purpose of harming people of African descent. Having framed the question in this way, they may conclude that there is little evidence of racism in Katrina events.

In contrast, people from various oppressed groups are more likely than White Americans to explain inequality or define racism in systemic terms (Bobo, 1998; Gurin, Miller, \& Gurin, 1980; Kluegel \& Smith, 1986; Sigelman \& Welch, 1991). When African Americans contemplate the issue of racism and Katrina, they may be more likely to think about institutions and structures that stigmatize people of African descent or that give White Americans greater access to resources (e.g., cash, credit cards, and automobiles) that enabled them to evacuate prior to the 
storm. Having framed the question in this way, they may conclude that there is abundant evidence that racism played a role in Katrina events.

\section{Relevant Research}

Evidence suggests that perceptions of racism in the aftermath of Katrina are highly influenced by the way people conceptualize racism (O'Brien, Adams, \& Nelson, 2006, unpublished manuscript). A questionnaire administered to a predominately White sample of students from Tulane University in New Orleans measured the extent to which participants defined racism in individualistic terms as opposed to systemic terms. In addition, participants indicated the extent to which they perceived racism in each of 17 separate Katrina-related events. The more participants defined racism in individualistic terms (and hence the less they defined it in systemic terms), the less racism they perceived in the aftermath of Katrina.

More generally, a growing body of research indicates that a broad conception of racism emphasizing systemic manifestations has scientific merit. Recent work has emphasized that the negative consequences of systemic oppression are not limited to intentional acts of bigoted individuals, but also take more subtle forms (see Dovidio \& Gaertner, 2004). Most of this research has emphasized how people who eschew explicit prejudice and consciously strive to act in a nonoppressive manner can still perpetrate subtle forms of "modern" bias that operate without intention or awareness (e.g., Fazio, Jackson, Dunton, \& Williams, 1995; Greenwald McGhee, \& Schwartz, 1998; Henkel, Dovidio, \& Gaertner, 2006; Kawakami, Dion, \& Dovido, 1999). These implicit or automatic manifestations of oppression imply a much larger role for racism in American society than mainstream representations admit or many White Americans may realize.

However, to the extent that it locates the consequences of systemic oppression in the (implicitly) biased actions of (unconsciously) bigoted actors, the emphasis on subtle forms still limits the notion of racism to direct acts of negative treatment directed against people from historically stigmatized groups. In contrast, an emerging tradition of research "from the target's perspective" extends conceptions of systemic oppression by demonstrating that the negative consequences of systemic oppression do not require direct acts of differential treatment (see Major \& O'Brien, 2005). Instead, the mere knowledge of systemic oppression can be sufficient to harm potential targets of that oppression-leading to academic underperformance (Steele, Spencer, \& Aronson, 2002), disidentification from prestigious activities (Major, Spencer, Schmader, Wolfe, \& Crocker, 1998), and decreased well being (Schmitt, Branscombe, \& Postmes, 2003) —even in the absence of oppressive or discriminatory treatment (see Adams, Garcia, Purdie, \& Steele, 2006).

Can adopting the perspective of the oppressed promote an expanded conception of racism in everyday events? Evidence of this possibility comes from re- 
search by Gurin, Lopez, and colleagues (Gurin, Nagda, \& Lopez, 2004; Gurin, Dey, Hurtado, \& Gurin, 2002; Lopez, 2004; Lopez et al., 1998). Two interesting patterns emerge from this research. First, increased exposure to diversity on college campuses increases the ability of White students to take the perspective of others (Gurin et al., 2002). Second, taking courses that address issues of race increases White students' awareness of racial inequality and their tendency to explain discrimination in systemic terms (Lopez, 2004; Lopez et al., 1998). In general, this research suggests that exposure to the perspective of the oppressed, whether through informal social contacts or classes that emphasize diversity, is positively related to indicators associated with perception of racism.

\section{Recovering Historical Memory}

Besides definitions of racism, the second tenet of a LP analysis-recovery of historical memory - suggests another source of information that may influence perceptions of racism: collective beliefs about past racism represented in constructions of history. The tendency for people from oppressed groups to perceive racism in society may occur not only because they apply relatively broad definitions of racism, but also because they have more knowledge about historically documented incidents of racism. Likewise, the tendency for people from dominant groups to perceive relatively little racism may occur not only because they apply narrow definitions, but also because they are less aware of historically documented incidents.

\section{Application to Katrina events}

To illustrate this idea in the context of Katrina, consider a cartoon that appeared in the October 12, 2005 installment of the syndicated comic strip Boondocks (McGruder, 2005). The cartoon featured an exchange between an African American man and child character, Huey.

Adult: Huey, you've got to let go of these ridiculous conspiracy theories. I assure you there is no way in a million years anyone would ever deliberately flood the poor Black parts of New Orleans.

Huey: Except when they did it in 1927.

Adult: Again, I'm sure it'll be a million years before they do that again.

The characters are referring to a belief noted earlier: the possibility that levees were deliberately breached in the aftermath of Hurricane Katrina. The adult character describes the belief as "ridiculous conspiracy theory," reproducing a prevalent representation of events in mainstream American settings, which implies that such beliefs are the product of ignorance, paranoia, or politically biased exaggeration (e.g., Fischer, 2005; Hicks, 2005; Tabacoff, 2005). 
Huey's reply frames this belief in a very different light. He refers to a historically documented case that occurred during the Mississippi flood of 1927. Fearing devastation from the rising river, rich New Orleanians sought to relieve pressure on levees that protected the city by dynamiting levees and intentionally flooding other areas, including poor Black communities in St. Bernard Parish. During and after the flood, African Americans (numbering as many as 300,000) were not only denied Red Cross supplies and forced to live in deplorable conditions at displacement camps, but also were compelled at gunpoint to repair the compromised levees. Resonating with accounts of Hurricane Katrina and its aftermath, accounts of the flood indicate that thousands of African Americans were left stranded, without food or water, and passed over by rescuers to evacuate White Americans (Barry, 1997; Moton, 1927).

Consistent with the guiding principle of a LP analysis, the point of Huey's response is to suggest that claims about racism in Katrina-like suspicion that flooding resulted from deliberate breach of the levees-may not be so "crazy" after all. Although such stories may seem unreal from mainstream American perspectives, they often resemble events in U.S. history-like the racist oppression perpetrated against people of African descent in the aftermath of the 1927 floodsfor which there is extensive documentation. People from oppressed groups may be more aware than people from dominant groups about these historically documented incidents of oppression, and this difference in historical knowledge, rather than ignorance or paranoia, may explain their tendency to perceive greater racism in Katrina events.

\section{Relevant Research}

Evidence for this account of group differences in perception of racism comes from a study that we conducted before the events of Hurricane Katrina among students at the University of Kansas and two historically Black universities (Howard University in Washington, DC, and Xavier University in New Orleans, LA; Nelson \& Adams, 2005, unpublished manuscript). In this study, we used a signal detection paradigm to create a measure of racist history detection (RHD). This procedure produces a statistic ( $d^{\prime}$ ') that distinguishes between the tendency to correctly identify historically documented incidents of racism as true and the tendency to indicate any allegation of past racism as true regardless of historical documentation (or "truth" status). In addition to this measure, we also included a survey that measured perceptions of racism via two sets of items. The first set referred to hypothetical cases of racism in isolated acts (e.g., Lashandra Jenkins and Amy Conner applied for the same job. They have nearly identical qualifications. Amy gets called for an interview and Lashandra does not). The second set referred to systemic racism embedded in the structures of American society (e.g., Portrayal of African Americans in entertainment media). 
Consistent with previous research (and responses to Katrina), scores on measures of racism perception were higher among African American students than European American students. Likewise, and regardless of race, scores on the measure of RHD were positively associated with the tendency to perceive racism across both types of items. However, Black students scored higher on the measure of RHD than did White students - that is, they were more likely to correctly identify historically documented items as true (i.e., hit rate), but no more likely to identify undocumented, "made-up" items as true (i.e., false alarm rate) — and this difference in RHD partly accounted for group differences in perception of racism for both types of items.

This pattern suggests that, rather than ignorance or distortion of reality (e.g., Fischer, 2005; Hicks, 2005; Tabacoff, 2005), beliefs about the plausibility of racism in Katrina events may be associated with more accurate knowledge of racism in U.S. history. Likewise, quick dismissal of claims about racism is not a straightforward indication of greater objectivity, but instead may reflect greater ignorance about documented incidents of past racism.

\section{Deideologizing Everyday Experience}

The preceding sections propose relatively "cognitive" or information-based explanations for group differences in the perception of racism. The third tenet of a LP analysis suggests the additional possibility that group differences in perception of racism may reflect divergent motivational pressures (Adams, Tormala, \& O'Brien, 2006). For example, research in social psychology has considered the possibility that African Americans may be motivated to perceive racism as a means to deflect blame for unsavory personal or group outcomes (for discussions, see Major, Quinton, \& McCoy, 2002; Schmitt \& Branscombe, 2002). ${ }^{2}$ One study compared beliefs about the plausibility of anti-Black conspiracies (e.g., "Some people say the virus that causes AIDS was deliberately created in a laboratory to infect Black people;" Crocker et al., 1999, p. 951) among African American and European American students. Results indicated that African American judgments of plausibility were not only significantly higher than European American judgments, but also were positively related to race-based collective self-esteem. The authors interpreted this pattern as evidence that African American students can use perception of racism as a strategy to buffer self-esteem from the negative consequences of oppression (Crocker et al., 1999).

An extreme form of the idea that people from oppressed groups are motivated to perceive racism as a strategy to protect group interests is the concept, mentioned

\footnotetext{
${ }^{2}$ An important body of research suggests that members of oppressed groups may also face motivations to minimize prejudice (see Major et al., 2002). However, because these motivations cannot account for group differences in perception of racism, we do not review this research here.
} 
by the journalist in the introduction to this article, of "playing the "race card" (Muhammed, 2005). This prevalent representation treats African American claims of racism as strategically motivated exaggeration. According to this idea, African Americans may be motivated to claim racism, even when it is not present, for personal and collective benefit.

There are two important ways in which a LP analysis challenges the "race card" account of group differences in perception of racism. The first concerns the pressures that might motivate people from oppressed groups to perceive racism. Rather than strategic or political motivations, a LP analysis emphasizes that people from oppressed groups may experience pressure to be vigilant for racism because they inhabit worlds where racist oppression is a dangerous reality. Working from a signal detection framework, scientists have suggested that members of oppressed groups will be motivated to be vigilant for prejudice to the extent that the cost associated with a false alarm is less than the cost of a miss (Feldman-Barrett \& Swim, 1998; Major et al., 2002). When the social environment is hostile and life threatening, the cost of not detecting oppression may be so great that people may be motivated to detect oppression for self-preservation purposes (Kaiser, Vick, \& Major, 2006; Major et al, 2002).

The second challenge is to direct attention from oppressed group claims about the presence of racism to White American claims about the absence of racism. Rather than an unbiased reading of objective reality, the latter claims may reflect ideological motivations of White Americans to deny racism, especially as a systemic phenomenon embedded in American society.

One set of motivations for White denial of racism concerns the need for positive social identity (Tajfel \& Turner, 1986). For White Americans, the perception of racism implies that one is (or could be) identified with a group responsible for perpetrating racism, violating an increasingly prevalent normative standard (Crandall, Eshleman, \& O’Brien, 2002; Dovidio \& Gaertner, 2004). Accordingly, White Americans may be motivated to deny the extent of racism to preserve an unprejudiced self-image and positive sense of White or American identity.

Another potential motivation for White denial of racism concerns the experience of collective guilt. Viewing White Americans as perpetrators of racial discrimination can lead to feelings of White guilt (Miron, Branscombe, \& Schmitt, 2006). White Americans may be motivated to ease feelings of guilt by denying the extent of racism (Harvey \& Oswald, 2000; Iyer, Leach, \& Crosby, 2003; Swim \& Miller, 1999).

Finally, perceptions of racism may be threatening because they imply that the social order is unjust or illegitimate (Kaiser, Dyrenforth, \& Hagiwara, in press). From their position of relative privilege, White Americans are more invested than are people from oppressed groups in maintenance of the status quo (Sidanius \& Pratto, 1999). To the extent that the admission of racism threatens the legitimacy of the status quo, Whites may be especially motivated to defend against this threat by denying or minimizing the extent of racism. 


\section{Application to Katrina Events}

These different motivational accounts have diverging implications when applied to the case of racism in Katrina events. Implicit in the phrase "playing the race card" is a denial of racism in Katrina events and a construction of claims about racism as strategically motivated exaggeration. In contrast, a LP analysis suggests that even if Black Americans experienced pressure to perceive racism in Katrina, it was not simply a form of strategic exaggeration. Instead, their responses may reflect reasonable vigilance in light of historical evidence suggesting that concern about racism may be justified. Moreover, a LP analysis suggests that, if group differences regarding perceptions of racism in Katrina do have a motivational source, it may lie with White Americans and motivations to deny racism.

\section{Relevant Research}

Research on aversive racism has demonstrated that White Americans deny the extent of their own personal prejudices (for a recent review see Dovidio \& Gaertner, 2004). In addition, we propose that White Americans may be motivated to deny the extent of racism in American society at large. Evidence for this proposition comes from three sources.

A first source of evidence is research that reports a negative relationship between various measures of White identity and (a) perceived plausibility of racist conspiracies (Crocker et al., 1999), (b) perceptions of racism in American society (Nelson \& Adams, 2005, unpublished manuscript), and (c) perceptions of racism in Katrina events (O'Brien et al., 2006, unpublished manuscript). Researchers have interpreted a positive relationship between identity concern and perceived plausibility of racist conspiracies as evidence that Black Americans are motivated to perceive racism (Crocker et al., 1999). This suggests that one can also interpret the negative relationship between identity concern and perception of racism or perceived plausibility of racist conspiracies as evidence that White Americans are motivated to deny racism.

A second source of evidence that White Americans may be motivated to deny racism concerns the identity relevance of different types of racism. In addition to measures of historical knowledge and racism perception in the study described above (Nelson \& Adams, 2005, unpublished manuscript), we also included two indicators of identification - the private regard subscale of the Collective SelfEsteem Scale (Luhtanen \& Crocker, 1992) and the Including the Ingroup in the Self Scale (Tropp \& Wright, 2001)—which participants completed with respect to both racial and American identity. Results indicated that perception of racism in isolated, hypothetical events was unrelated to indicators of identification. In contrast, perception of systemic manifestations of racism was positively related to indicators of Black racial identification among African American students, but 
negatively related to indicators of both White racial identification among European American students and American identification among all students.

Besides demonstrating again the link between identity and perception of racism, results of this study extend previous research in two important ways. First, results suggest that the link to identity is stronger for perception of racism in systemic manifestations - which have implications for perceived legitimacy of existing status distinctions - than in isolated, hypothetical events. Second, these results provide evidence that perception of racism has implications not only for experience of racial identity, but also for experience of American identity (regardless of ethnic identity).

A third source of evidence that White Americans may be motivated to deny racism comes from two experiments in which we manipulated ego-defensive motivational pressures via a self-affirmation procedure and then observed the effect of this manipulation on subsequent perceptions of anti-Latino racism (Adams, Tormala, \& O'Brien, 2006). Participants in this research were Anglo and Latino college students in Southern California whom we assigned at random to write an essay about either the personal relevance of their most important value (affirmation condition) or the relevance for another student of a personally unimportant value (no-affirmation condition). We then observed the effect of this manipulation on a survey that measured perceptions of anti-Latino racism in both isolated acts (e.g., A Latino student went to a job interview at a corporation. The firm told him he could have the job if he agreed to cut his hair.) and more systemic manifestations (e.g., Ballot initiatives that eliminate educational and medical services to undocumented immigrants).

Consistent with an accumulating body of research, results of both experiments indicated that Latino participants perceived greater racism than did Anglo participants. However, this group difference in perception of racism was smaller among participants in the affirmation condition-which reduces defensive pressures to challenge information that poses threats to the self-than in the no-affirmation condition. Follow-up analyses indicated that this pattern was primarily due to a tendency among Anglo students in the affirmation condition to indicate significantly higher perception of racism than did Anglo students in the no-affirmation condition. (Although there was some evidence that the affirmation treatment reduced perception of racism among Latino participants, evidence was weak and inconsistent across the two studies. $)^{3}$ Results are consistent with the interpretation that the affirmation treatment reduced the pressure on Anglo students to deny the

\footnotetext{
${ }^{3}$ In this study, we did not assess the hypothesis that either (a) ethnic differences or (b) effects of the affirmation manipulation would be greater for perception of racism in systemic forms than in isolated events. A reanalysis of data indicated the hypothesized pattern of results for (a) such that the ethnic difference was greater for systemic forms $(M=4.59, S D=.99$ for Latino versus $M=3.65, S D=1.12$ for Anglo) than for isolated events ( $M=5.18, S D=1.02$ versus $M=4.42, S D=1.06$, respectively). Likewise, this reanalysis indicated the hypothesized pattern of results for (b) among Anglo participants such that the effect of the affirmation manipulation was greater for systemic forms $(M=3.34, S D=$ 1.06 for no-affirmation versus $M=3.97, S D=1.11$ for affirmation) than for isolated events $(M=4.21$,
} 
extent of racism, thereby freeing them to recognize higher levels of racism than Anglo participants in the no-affirmation condition.

\section{Implications for Policy}

Consistent with its primary intellectual strategy, the overall policy recommendation that follows from a LP analysis is a call to design policies and promote institutions that mindfully include perspectives of the oppressed. We briefly describe two policies-affirmative action and multiculturalism-designed to accomplish this objective. We then consider the implications of a LP perspective for important policy objectives in the context of Katrina.

\section{Policy Recommendations}

\section{Affirmative Action}

One way to include perspectives of the oppressed is through various policies of affirmative action that actively promote institutional participation of people from oppressed groups (see Crosby, 2004). Applied to the post-Katrina context, affirmative action policies have (at least) two benefits.

First, these policies provide opportunities for voices of the oppressed to influence rebuilding decisions by redefining relevant issues. The mere presence of people from historically oppressed groups can change the way people from dominant groups understand a policy-relevant situation, influencing them to reconstruct situations in ways that resonate with the perspective of the oppressed (Sommers, 2006). An important example concerns representations of the post-Katrina rebuilding effort as an opportunity for economic development and growth. Despite positive connotations of development and growth, these representations imply a form of ethnic cleansing: displacement of poor, predominantly Black communities to make way for commercial interests (Davis, 2005). Policies of affirmative action provide opportunities for oppressed voices to challenge these representations of economic development and to promote alternative representations (e.g., as an opportunity to revitalize pre-existing communities) that resonate more strongly with the perspective of the oppressed.

Second, affirmative action policies can improve effectiveness of rebuilding operations by fostering an atmosphere of intergroup trust. To the extent that increased participation of people from oppressed groups promotes a sense of increased voice in the decision-making process, affirmative action may enhance the perceived legitimacy of resulting decisions among people from oppressed groups. In turn,

$S D=.92$ versus $M=4.64, S D=1.17$, respectively). However, the corresponding Ethnicity $\times$ Racism Type (within Anglo students) and Affirmation $\times$ Racism Type interactions were not significant, $F$ s $(1$, $93)<1.1, p s>.30$. 
perceived legitimacy may increase cooperation with rebuilding policies and reduce accusations of racism in the recovery effort.

\section{Multiculturalism}

Another way to include perspectives of the oppressed is via policies of multiculturalism that actively build oppressed voices into the official constructions of reality that inform decisions of mainstream institutions. One reference here is to representations of history and American identity in textbooks and museums (Loewen, 1996; 1999) that come to terms with the legacy of racism in the U.S. society. Applied to the Katrina context, policies of multiculturalism may promote official accounts of the disaster that include voices of the oppressed and resist the pressure to "whitewash" evidence of racism and thereby preserve a positive sense of American identity (Brown et al., 2003; see Riggs \& Augoustinos, 2005, with respect to Australian identity).

The phrase "official constructions of reality" also refers to definitions of oppression that recognize a broad range of mechanisms - besides hostility-motivated, direct differential treatment-through which racism can cause harm (Krieger, 2004). Applied to the context of Katrina, the change in definitions implies a shift in attention away from questions of blame for the disaster, which tend to generate defensiveness and denial of racism or wrongdoing. Instead, the emphasis on broad systemic roots of racism in Katrina may allow people in positions of dominance to focus on remediation of harm without the psychologically and politically painful admission of personal or collective guilt.

\section{Implications for Policy Objectives}

Perhaps the most important policy-relevant consequence that follows from a LP analysis is a greater consciousness of racism and oppression in American society (see Freire, 1970, on conscientização). A LP analysis contributes to this result by proposing broader definitions of racism, "recovering historical memory" of racism, and illuminating the phenomenon of privilege (including the power to impose definitions of racism or representations of history on mainstream institutions). In turn, consciousness about racism has implications for important policy objectives.

\section{Promoting Social Justice}

The primary policy objective for a LP analysis is the goal of social justice. Consciousness about the extent of racism in American society promotes this objective in many ways. First, it implies less victim-blaming explanations for oppressed group outcomes. For example, people who have greater awareness about the 
extent of systemic racism may grant greater weight to socioeconomic constraints than to allegedly irresponsible behavior as the reason for relatively low evacuation rates in African American communities before Katrina struck. Second, by implying an ongoing need for antiracist action, consciousness about the extent of racism may foster support for policies - affirmative action practices, antidiscrimination laws, and (in the aftermath of Katrina) voting rights protections - designed to counteract the effects of racism and oppression.

For people from oppressed groups, recognition of oppression may defuse any tendencies to blame their own group for its less favorable social position (Major et al., 2002; Martín-Baró, 1994), and encourage reinterpretation of social identities bestowed on them by the dominant culture (Adams, Fryberg, Garcia, \& DelgadoTorres, 2006). In turn, the production of prouder, less blameworthy identities may promote ingroup identification (Branscombe, Schmitt, \& Harvey, 1999) and facilitate collective action to fight injustice and oppression (Gurin \& Townsend, 1986; Major et al., 2002). Although the recognition of oppression may take some toll on well being (e.g., Schmitt et al. 2003), it may also be necessary and adaptive to the extent that it alerts people from oppressed groups to the ongoing threats that they face in a racist society (Kaiser et al., 2006). For example, awareness of oppression has made people appropriately vigilant for injustice during the post-Katrina rebuilding process and has stimulated collective action to fight gentrification and relocation of poor Black residents to less desirable locations (Rivlin, 2006).

\section{Defusing Intergroup Conflict}

Vigilance for racism is not without costs and may take a toll on people from oppressed groups through increased stress and associated physiological problems (e.g., hypertension; Clark, Anderson, Clark, \& Williams, 1999). Likewise, vigilance implies a low criterion for perceiving racism that, although reasonable (and perhaps necessary) in light of historical evidence, may nevertheless lead to "false alarms": claims of racism that other people, or the same person at another time, would conclude are mistaken. False alarms can be harmful in cases like Katrina to the extent that they lead people from oppressed groups to oppose policies that are truly unbiased (Cohen, Steele, \& Ross, 1999), distract attention from more deserving concerns (including more serious instances of oppression), and create suspicion that fosters interpersonal rejection and intergroup conflict (MendozaDenton, Downey, \& Purdie, 2002).

Rather than deny that some claims of racism in Katrina may be false alarms, a LP analysis - and particularly the strategy of adopting the perspective of the oppressed-promotes an alternative construction of such cases. Implicit in the notion of "playing the race card" is a construction of claims about racism as deviations from a baseline of nonracism and an associated sense that the burden of proof lies with people making claims of racism to show that they are true. 
In contrast, a LP analysis frames such claims as reasonable within a historical baseline of racism and implies that some burden of proof lies with people who dispute such claims to show that they are false. Broader consciousness about the extent of racism in American society can defuse intergroup conflict in the aftermath of Katrina by promoting understanding of the basis for claims about racism (even if one personally believes that a particular claim is false). Moreover, to the extent that people from dominant groups can convey this understanding, they may contribute to an atmosphere of enhanced trust that not only reduces intergroup conflict, but also eases the vigilance that affords false alarms in the first place.

\section{Liberating American Identity}

Although heightened consciousness about racism may promote social justice, it also threatens prevailing constructions of American identity. As evidence of this threat, our research indicates that strength of American identity was negatively correlated with perceptions of racism in Katrina events (O'Brien et al., 2006, unpublished manuscript). Threat to American identity may explain why many people vigorously denied allegations of racism in the aftermath of Katrina and labeled such allegations divisive, irresponsible, or unpatriotic (Bozell, 2005; Elder, 2005; Goldberg, 2005; Jacoby, 2005; Leo, 2005). Such denial of racism not only eases the pain of identity threat, but also protects the sense of national unity and moral purpose that underlie constructions of American identity.

Despite its short-term, identity-enhancing benefits, a LP analysis suggests that denial of racism will have long-term costs to the extent that it fails to deal decisively with an important reality: the unresolved legacy of racist oppression that underlies threats to American identity. As a result of this unresolved threat, people who are highly identified with American may feel pressure to deny that racism played a role in Katrina events, even when less interested observers would conclude that racism did play a role. Alternatively, the perception of racism in Katrina events may lead people to disidentify with the category American, especially to the extent that available conceptions of American identity do not recognize a role for racism in current events.

In order to promote patriotism and positive social identity, official constructions of history (e.g., school curricula, museums, and monuments) often overstate the positive achievements of a society and tend to "repress" wrongdoings from collective memory (Loewen, 1996; Reicher \& Hopkins, 2002). ${ }^{4}$ As a result (and to some extent regardless of their individual motives), people well versed in official representations of American history may be relatively unaware of past incidents of oppression, leaving them ill-prepared to recognize incidents of racism in events

\footnotetext{
${ }^{4}$ For a discussion of the dialectical tension between accuracy and identity functions in collective and autobiographical memory, see Wertsch (2002) or Wilson and Ross (2003).
} 
like Katrina. An important task for application of a LP approach is the articulation of alternative representations of the American identity that reflect the historical experience of all people in the American society - and "recover" memory of systemic oppression-rather than reflect the perspectives and protect the interests of a dominant subset (Riggs \& Augoustinos, 2005). Such representations will not only provide a strong foundation for recognizing racist injustice, but also will liberate American identity from the pressure to deny the extent of past and present racism. In this way, the liberation associated with a LP analysis is not limited to people from oppressed groups, but also applies to American society in general.

\section{References}

Adams, G., Fryberg, S., Garcia, D. M., \& Delgado-Torres, E.U. (2006). The psychology of engagement with Indigenous identities: A cultural perspective. Cultural Diversity and Ethnic Minority Psychology, 12, 493-508.

Adams, G., Garcia, D. M., Purdie-Vaughns, V., \& Steele, C. M. (2006). The detrimental effects of a suggestion of sexism in an instruction situation. Journal of Experimental Social Psychology, $42,602-615$.

Adams, G., Tormala, T. T., \& O’Brien, L. T. (2006). The effect of self-affirmation on perception of racism. Journal of Experimental Social Psychology, 42, 616-626.

Barry, J. M. (1997). Rising tide: The great Mississippi flood of 1927 and how it changed America. New York: Simon \& Schuster.

Beaumont, P. (2005, December 11). Drowned city cuts its poor adrift. Guardian Unlimited. Accessed on December 11, 2005 from http://environment.guardian.co.uk/climatechange/story/O, 1849448, oo.html

Bobo, L. (1998). Race interests and beliefs about affirmative action: Unanswered questions and new directions. American Behavioral Scientist, 41, 985-1003.

Bond, J. (2005). Statement from NAACP Chairman Julian Bond. Accessed on October 31, 2005 from http://www.sanjosenaacp.org/katrina.htm

Bozell, L. B. (2005, September 7). Cheering on racial division. Syndicated column posted to Accessed on October 4, 2005 http://www.mrc.org/BozellColumns/newscolumn/2005/col20050907.asp.

Branscombe, N. R., Schmitt, M. T., \& Harvey, R. D. (1999). Perceiving pervasive discrimination among African Americans: Implications for group identification and well-being. Journal of Personality and Social Psychology, 77, 135-149.

Brown, M. K., Carnoy, M., Currie, E., Duster, T., Oppenheimer, D. B., Shultz, M. M., \& Wellman, D. (2003). Whitewashing race: The myth of a color-blind society. Berkeley, CA: University of California Press.

Brown, M. (2005, September 22). Bridge emphasized divide between communities. Times-Picayune. Accessed on October 20, 2005 from http://www.nola.com/t-p/archive.ssf?/mtlogs/nola tporlcans/archives/2005_09_22.html/081762

Clark, R., Anderson, N. B., Clark, V. R., \& Williams, D. R. (1999). Racism as a stressor for African Americans. American Psychologist, 54, 805-816.

Cohen, G. L., Steele, C. M., \& Ross, L. D. (1999). The mentor's dilemma: Providing critical feedback across the racial divide. Personality and Social Psychology Bulletin, 25, 1302-1318.

Crandall, C. S., Eshleman, A. \& O'Brien, L. (2002). Social norms and the expression and suppression of prejudice: The struggle for internalization. Journal of Personality and Social Psychology, $82,359-378$.

Crocker, J., Luhtanen, R., Broadnax, S., \& Blaine, B. E. (1999). Belief in U.S. government conspiracies against Blacks among Black and White college students: Powerlessness or system blame? Personality and Social Psychology Bulletin, 25, 941-953. 
Crosby, F. (2004). Affirmative action is dead: Long live affirmative action. Harrisonburg, VA: R.R. Donnelley.

Crowley, A. (2005, September 12). Farrakhan visits Charlotte, criticizes federal response. Accessed on October 31, 2005 from http://www.wcnc.com/news/topstories/stories/091205-ad-wcncfarrakhan.4fb21767.html

Davis, M. (2005, October 25). Gentrifying disaster. In New Orleans: Ethnic Cleansing, GOP-style. Mother Jones. Accessed October 25, 2005 from http://motherjones.org/commentary/columns/ 10/gentrifying disaster/html

Dovidio, J. F., \& Gaertner, S. L. (2004). Aversive racism. In M. P. Zanna (Ed.), Advances in experimental social psychology (Vol. 36, pp. 1-52). New York, NY: Academic Press.

Elder, L. (2005, September 8). Katrina, the race card, and the welfare state. Townhall.com. Accessed on November 1, 2005 from http://www.townhall.com/opinion/columns/larryelder/2005/09/08/ 155368.html.

Fazio, R. H., Jackson, J. R., Dunton, B. C., \& Williams, C. J. (1995). Variability in automatic activation as an unobtrusive measure of racial attitudes: A bona fide pipeline? Journal of Personality and Social Psychology, 69, 1013-1027.

Feldman-Barrett, L., \& Swim, J. K. (1998). Appraisals of prejudice and discrimination. In J. K. Swim \& C. Stangor (Eds.) Prejudice: The target's perspective (pp. 12-37). San Diego, CA: Academic Press.

Fischer, B. (Executive Producer). (2005, September 18). Meet the Press [Television broadcast]. New York and Washington, DC: NBC-TV network.

Fiske, A. P., Kitayama, S., Markus, H. R., \& Nisbett, R. E. (1998). The cultural matrix of social psychology. In D. T. Gilbert \& S. T. Fiske (Eds.), The handbook of social psychology (4th ed.,Vol. 2,pp. 915-981). Boston: McGraw-Hill.

Freire, P. (1970). Pedagogy of the oppressed. New York: Herder and Herder.

Gergen, K. J., Gulerce, A., Lock, A., \& Misra, G. (1996). Psychological science in cultural context. American Psychologist, 51, 496-503.

Goldberg, J. (2005, September 7). In Katrina's aftermath, racial generalizations aren't helpful. Townhall.com. Accessed on November 1, 2005 from http://www.townhall.com/opinion/columns/ jonahgoldberg/2005/09/07/155355.html.

Greenwald, A. G., McGhee, D. E., \& Schwartz, J. L. K. (1998). Measuring individual differences in implicit cognition: The implicit association test. Journal of Personality and Social Psychology, $74,1464-1480$.

Griffin, D. \& Ross, L. (1991). Subjective construal, social inference, and human misunderstanding. In M. P. Zanna (Ed.), Advances in experimental social psychology (Vol. 24, pp. 319-358). New York: Academic Press.

Gurin, P., Dey, E. L., Hurtado, S., \& Gurin, G. (2002). Diversity and higher education: Theory and impact on educational outcomes. Harvard Educational Review, 72, 330-366.

Gurin, P., Miller, A. H., \& Gurin, G. (1980). Stratum identification and consciousness. Social Psychology Quarterly, 43, 30-47.

Gurin, P. Nagda, B. A., \& Lopez, G. E. (2004). The benefits of diversity in education for democratic citizenship. Journal of Social Issues, 60, 17-34.

Gurin, P., \& Townsend, A. (1986). Properties of gender identity and their implications for gender consciousness. British Journal of Social Psychology, 25, 139-148.

Harvey, R., \& Oswald, D. L. (2000). Collective guilt and shame as motivation for White support of Black programs. Journal of Applied Social Psychology, 30, 1790-1811.

Henkel, K. E., Dovidio, J. F., \& Gaertner, S. L.2006. Institutional Discrimination, Individual Racism, and Hurricane Katrina. Analyses of Social Issues and Public Policy.

Herbert, B. (2005, September 12). A rush of stories. New York Times, p. A 21.

Hicks, J. R. (2005, October 2). Levees let loose an ugly flood of Black paranoia. Los Angeles Times. Accessed on October 25, 2005 from http://www.latimes.com/news/printedition/suncommentary/laopracc2octo2,1,2511487.story?coll-la-headlines-suncomment.

Iyer, A., Leach, C. W., \& Crosby, F. J. (2003). White guilt and racial compensation: The benefits and limits of self-focus. Personality and Social Psychology Bulletin, 29, 117-129.

Jacoby, J. (2005, September 14). Katrina's colorblind relief. The Boston Globe. Accessed on October 24, 2005 from http:/www.townhall.com/columnists/jeffjacoby/2005/09/15/katrinas_colorblind_ relief. 
Johnson, J. D., Simmons, C., Trawalter, S., Ferguson, T., \& Reed, W. (2003). Observer race and White anti-Black bias: Factors that influence and mediate attributions of "ambiguously racist" behavior. Personality and Social Psychology Bulletin, 29, 609-622.

Kaiser, C. R., Dyrenforth, P. S. \& Hagiwara, N. (in press). Why are attributions to discrimination interpersonally costly?: A test of status legitimizing and group justifying motives. Personality and Social Psychology Bulletin.

Kaiser, C. R., Vick, S. B., \& Major, B. (2006). Prejudice expectations moderate preconscious attention to social identity threatening cues. Psychological Science, 17, 332-338.

Kawakami, K., Dion, K. L., \& Dovido, J. F. (1999). Implicit stereotyping and prejudice and the primed Stroop task. Swiss Journal of Psychology, 58, 241-250.

Kinney, A. (2005, September 1). "Looting" or "Finding": Bloggers are outraged over the different captions on photos of Blacks and Whites in New Orleans. Salon.com. Accessed on October 31, 2005 from http://www.salon.com/news/feature/2005/09/01/photo_controversy/index_np.html.

Klein, N. (2005, September 22). Purging the poor. The Nation. Accessed October 24, 2005 from http://www.thenation.com/doc/20051010/klein.

Kluegel, J. R., \& Bobo, L. (1993). Dimensions of Whites' beliefs about the Black-White socio-economic gap. In P. M. Sniderman, P. E. Tetlock, \& E. G. Carmines (Eds.), Prejudice, politics, and the American dilemma (pp. 127-147). Stanford, CA: Stanford University Press.

Kluegel, J. R., \& Smith, E. R. (1986). Beliefs about inequality: Americans' views of what is and what ought to be. Hawthorne, NY: De Gruyter.

Krieger, L. H. (2004). The intuitive psychology behind the bench: Models of gender bias in social psychology and employment discrimination law. Journal of Social Issues, 60, 835848.

Leo, J. (2005, September 19). Failure's many fathers. U.S. News \& World Report. Accessed October 25, 2005 from http://www.usnews.com/usnews/opinion/articles/050919/19john.htm.

Loewen, J. W. (1996). Lies my teacher told me: Everything your American history textbook got wrong. New York: Touchstone.

Loewen, J. W. (1999). Lies across America: What our historic sites get wrong. New York: New Press.

Lopez, G. E. (2004). Interethnic contact, curriculum, and attitudes in the first year of college. Journal of Social Issues, 60, 75-94.

Lopez, G. E., Gurin, P., \& Nagda, B. A., (1998). Education and understanding structural causes for group inequalities. Political Psychology, 19, 305-329.

Luhtanen, R., \& Crocker, J. (1992). A collective self-esteem scale: Self-evaluation of one's social identity. Personality and Social Psychology Bulletin, 18, 302-318.

Major, B. N., \& O'Brien, L. T. (2005). The social psychology of stigma. Annual Review of Psychology, $56,393-421$.

Major, B. N., Quinton, W. J., \& McCoy, S. K. (2002). Antecedents and consequences of attributions to discrimination: Theoretical and empirical advances. In M. P. Zanna (Ed.), Advances in experimental social psychology (Vol. 34, pp. 251-330). New York, NY: Academic Press.

Major, B., Spencer, S., Schmader, T., Wolfe, C., \& Crocker, J. (1998). Coping with negative stereotypes about intellectual performance: The role of psychological disengagement. Personality and Social Psychology Bulletin, 24, 34-50.

Martín-Baró, I. (1994). Writings for a liberation psychology. (A. Aron \& S. Corne, Eds.) Cambridge, MA: Harvard University Press.

McGruder, (2005, October 12). Boondocks. [Comic strip]. Washington Post.

Mendoza-Denton, R., Downey, G., Purdie, V. J. (2002). Sensitivity to status-based rejection: Implications for African American students' college experience. Journal of Personality and Social Psychology, 83, 896-918.

Miron, A. M., Branscombe, N. R., \& Schmitt, M. T. (2006). Collective guilt as distress over illegitimate intergroup inequality. Group Processes and Intergroup Relations, 9, 163-180.

Moscovici, S. (1984). The phenomena of social representations. In R. M. Farr \& S. Moscovici (Eds.), Social representations (pp. 3-69). Cambridge, England: Cambridge University Press.

Moton, R. R. (1927, May) Colored Advisory Commission Appointed to Cooperate with The American National Red Cross and the President's Committee on Relief Work in the Mississippi Valley Flood Disaster of 1927. Herbert Hoover Presidential Library, National Archives and Records Service. 
Muhammad, A. (2005, September 2). Is it Darfur yet?. Accessed October 25, 2005 from http:// www.bet.com/Site+Management/Packages/askiablog1.htm?mb=1.

Nagel, T. (1986). The view from nowhere. New York: Oxford University Press.

Nelson, J.C., \& Adams, G. (2005). The roles of historical knowledge and identity in perceptions of racism. Unpublished manuscript.

O'Brien, L.T., Adams, G., \& Nelson, J.C.. (2006). Perceptions of racism in the aftermath of Hurricane Katrina: A survey of students living in New Orleans. Unpublished manuscript.

Operario, D., \& Fiske, S. T. (2001). Ethnic identity moderates perceptions of prejudice: Judgments of personal versus group discrimination and subtle versus blatant bias. Personality and Social Psychology Bulletin, 27, 550-561.

Page, S., \& Puente, M. (2005, September 12). Poll shows racial divide on storm response. USA TO$D A Y$. Accessed on September 12, 2005 from http://www.usatoday.com/news/nation/2005-0912-katrina-poll_x.htm.

Pew Research Center for People and the Press (2005, September 8). Huge racial divide over Katrina and its consequences. Accessed on October 17, 2005 from http://people-press.org/reports/pdf/255. pdf

Reicher, S. \& Hopkins, N. (2002). Self and nation: Categorization, contestation and mobilization. London: Sage

Reuters (2005, October 15). Farrakhan wants govt sued over hurricane response. Accessed on October 31, 2005 from http://today.reuters.com/news/newsArticleSearch.aspx?storyID=10668+16Oct-2005+RTRS\&srch=Farrakhan+wants+govt+sued+over+hurricane+response

Riggs, D. W., \& Augoustinos, M. (2005). The psychic life of colonial power: Racialised subjectivities, bodies and methods. Journal of Community and Applied Social Psychology, 15, 461477.

Rivlin, G. (2006, January 12). Anger meets New Orleans renewal plan. New York Times, p. A 18.

Rodin, M. J., Price, J. M., Bryson, J. B., \& Sanchez, F. J. (1990). Asymmetry in prejudice attribution. Journal of Experimental Social Psychology, 26, 481-504.

Ross, L., \& Ward, A. (1996). Naïve realism in everyday life: Implications for social conflict and misunderstanding. In E. S. Reed, E. Turiel, \& T. Brown (Eds.) Values and knowledge. The Jean Piaget symposium series. (pp. 103-135). Hillsdale, NJ: Lawrence Erlbaum Associates, Inc.

Schmitt, M. T., \& Branscombe, N. R. (2002). The meaning and consequences of perceived discrimination in disadvantaged and privileged social groups. European Review of Social Psychology, $12,167-199$.

Schmitt, M. T., Branscombe, N. R., \& Postmes, T. (2003). Women's emotional responses to the pervasiveness of gender discrimination. European Journal of Social Psychology, 33, 297312.

Sidanius, J., \& Pratto, F. (1999). Social dominance: An intergroup theory of social hierarchy and oppression. New York, NY: Cambridge University Press.

Sigelman, L., \& Welch, S. (1991). Black Americans views of inequality. New York, NY: Cambridge University Press.

Sommers, S. R. (2006). On racial diversity and group decision making: Identifying multiple effects of racial composition on jury deliberations. Journal of Personality and Social Psychology, 90, 597-612.

Steele, C. M., Spencer, S. J., \& Aronson, A. (2002). Contending with group image: The psychology of stereotype and social identity threat. In M. P. Zanna (Ed). Advances in experimental social psychology (Vol. 34, pp. 379-440). San Diego, CA: Academic Press.

Swim, J. K., \& Miller, D. L. (1999). White guilt: Its antecedents and consequences for attitudes toward affirmative action. Personality and Social Psychology Bulletin, 25, 500-514.

Tabacoff, D. (Executive Producer). (2005, October 18). The O'Reilly Factor. [Television broadcast]. Fox News Channel.

Tajfel, H., \& Turner, J. C. (1986). The social identity theory of intergroup behavior. In S. Worchel \& W. G. Austin (Eds). Psychology of Intergroup Relations. Chicago, IL: Nelson Hall.

Tropp, L. R. \& Wright, S. C. (2001). Ingroup identification as the inclusion of ingroup in the self. Personality \& Social Psychology Bulletin, 27, 585-600. 
Washington, A. (2005, September 6). Timidity no answer to racism in Katrina debacle. The Washington Times. Accessed October 24, 2005 from http://washingtontimes.com/metro/20050905-1112152608r.htm.

Wertsch, J. V. (2002). Voices of collective remembering. New York: Cambridge University Press.

Wilson, A. E., \& Ross, M. (2003). The identity function of autobiographical memory: Time is on our side. Memory, 11, 137-149.

GLENN ADAMS, Department of Psychology, University of Kansas, and Department of Psychology, University of Toronto.

LAURIE T. O’BRIEN, Department of Psychology, Tulane University.

JESSICA C. NELSON, Department of Psychology, University of Kansas. 
